The average speed has risen substantially. Oilburning and motor-vessels have replaced the old coal burners. The British merchant marine, as well as being the world's largest, is one of the most efficient; less than 45 per cent of the ships have a top speed below 12 knots and 24 per cent have a speed in excess of 15 knots. In 1938 Great Britain launched only one million gross tons of new shipping as compared with 1.9 millions in 1913 . It is considered probable that the 1940 total will approximate three million tons. For the first time in many years, shipyards in Canada and other parts of the Empire are working at full capacity. This activity will increase the new tonnage available for the replacement of losses and the continued expansion of the services made necessary by the exigencies of the War.

\section{STRUCTURAL HINGES OF REINFORCED CONCRETE}

$I^{\mathrm{N}}$ reinforced-concrete, rigid-frame bridges, particularly in those of long spans, it is desirable, and in many cases necessary, to introduce some form of articulation at the bases of vertical members where high deformation stresses would otherwise occur due to temperature changes and shrinkage. What constitutes a suitable hinge for such a structure can be determined only by laboratory tests in conjunction with field experience, and a paper which has recently been issued (Bulletin No. 322, Engineering Experiment Station, University of Illinois) entitled "An Investigation of Rigid Frame Bridges : Part 3. Tests of Structural Hinges of Reinforced Concrete", by R. W. Kluge, deals with this important aspect of reinforced concrete design.

The purpose of the investigation described was to obtain information relative to the structural behaviour of several types of hinges adaptable to concrete rigid-frame bridges. Besides being sufficiently flexible to permit the required degree of rotation, a properly designed hinge should be capable of withstanding both compressive and shear forces, be economical to construct and easy to maintain, and the seven examples selected for test were such as might be expected to meet these requirements.

The specimens, which included tongue and groove joints, simple pivots, a modified Mesnager hinge and a flexure fulcrum hinge, were, with one exception, made from concrete designed to have a strength of $3,500 \mathrm{lb}$. per square inch at 28 days and were tested to destruction under vertical loads, oblique loads and rotation and time loads.

While the limited scope of the investigation did not permit of any general conclusions being reached, the results provide a basis for further study. They do, however, give information as to the most suitable designs for a given type of bridge and show that under vertical load the measured strength is in close conformity with the computed strength. In most cases, favourable figures under oblique load were recorded, while, with one exception, they all permitted an angular rotation of 0.004 radian without deterioration even after 10,000 reversals. Pending more detailed investigation, the details supplied in this bulletin are therefore of considerable importance and value to designers.

\section{APPOINTMENTS VACANT}

APPLICATIONS are invited for the following appointments on or before the dates mentioned:

LeCturer in MeChanicat Engineering SubJects at the Oxford Schools of Technology, Art and Commerce-The Chief Education Officer, City Education Office, 77 George Street, Oxford (August 28). LeOTurer IN MEChanical EngineERing-The Principal, County Technical College, Gainsborough, Lincs. (August 29).

Lecturer in Mechanical Engingering - The Principal, County

Technical College, Gainsborough, Lincs. (August 29).

DEPUTY DIRECTOR OF EDDCATION-The Director of Education and Chief Executive Officer, Education Offices, 263 \#igh Street, Walthamstow, London, E.17 (August 31).

Professor of Physical Chemistry in the University of the Punjab, Lahore-The Secretary, Universities Bureau, 88a Gower Street, W.C. (September 1).

Professor of Anatomy at St. Mary's Hospital Medical SchoolThe Academic Registrar, University of London, Royal Holloway College, Englefleld Green, Surrey (September 11).

Assistant Secretary for Higher Eddoation-The Secretary for Education, County Offices, Aylesbury, Bucks. (September 27).

LECTURER with an Honours Degree in either ENGINEERING or MATHwMATrCs at the Royal Technical College, Salford-The Acting Director of Education, Education Office, Salford 3.

Lecturers in Chemistry, Physics, PURe and Applifed MatheMATICS, and ENGINEERING DRAWING, for Senior Day and Evening Classes, and LECTURERS in BUILDING SCIENCE S.3, ELECTRICA. TECHNOLOGY A.2, TRANSMISSION and DISTRIBUTION A.2, RADIO-COMMUNICATIONS, and MECHANICAL ENGINEERING SUBJECTS, for Senio Thames.

Teacher of Mechanioal Enginemerng in the Smethwick Municipal College - The Chief Education Officer, Education Offices, 215 High Street, Smethwick.

Drainage AND IRRIgation ENginefer to the Government of Sierra Leone-The Crown Agents for the Colonies, 4 Millbank, S.W.1 (quoting

\section{REPORTS AND OTHER PUBLICATIONS}

(not included in the monthly Books Supplement) Great Britain and Ireland

Transactions of the Royal Society of Edinburgh. Vol. 60, Part 1, No. 7 : The Origin of Frogg. By Prof. D. M. S. Watson. Pp. 195-232. (Edinburgh: Robert Grant and Son, Ltd.; London: Williams and Norgate, Ltd.). $48.6 d$.

The Efficiency of Commercial Pasteurisation and the Phosphatase Test. By Ben Davies. Pp. 40. (London: United Dairies, Ltd.) [98

\section{Other Countries}

Henry Lester Institute of Medical Research. Annual Report, 1939. Pp. $58+3$ plates. (Shanghai : Henry Lester Institute for Medical Research.)

Imperial College of Tropical Agriculture: Low Temperature Research Station. Memoir No. 16: Studies in Tropical Fruits, viii. Carbohydrate Metabolism of the Banana Fruit during Development. By H. R. Barnell. Pp. 39-72. (Trinidad: Imperial College of Tropica] Agriculture.)

Annual Report for the Year 1939 of the South African Institute for Medical Research. Pp. 85. (Johannesburg: South African Institute for Medical Research.)

Durban Museum and Art Gallery. Annual Report for the Year ended 31st July 1939. Pp. $12+4$ plates. (Durban: Durban Museum and Art Gallery.)

Union of South Africa : Department of Mines. Memoir No. 37: Subject Index to the Literature of South African Geology and Mineral Resources for the Years 1921 to 1935 (inclusive). By Dr. A. L. Hall. Pp. 288. (Pretoria : Government Printer.) 78. 6d. [88 Contributions from the United States National Herbarium. Vol. 28, Part 3: Marine Algæ of the Smithsonian-Hartford Expedition to the West Indies, 1937. By William Randolph Taylor. Pp. iii +549 $562+$ plate 20 . (Washington, D.C.: Government Printing Office.) [98
Brooklyn Botanic Garden Record. Vol, 29, No. 3: Gardens within a Garden; a General Guide to the Grounds of the Brooklyn Botani Garden. By C. Stuart Gager. (Guide No. 10.) Second edition. Pp. 155-214. (Brooklyn, N.Y. : Brooklyn Institute of Arts and
Sciences.) 25 cents.

U.S. Department of the Interior : Office of Education. Vocational Division Bulletin No. 13 (Agricultural Series No. 1): Agricultural Education, Organization and Administration. Revised edition. Pp. vi +50. 10 cents. Vocational Division Bulletin No. 206 (Home Economics Series No. 23): Credit Problems of Families; a Study of Credit as a Phase of Family Financial Planning; Suggestions to Homemaking Teachers. Pp. vii $+100+3$ plates. 20 cents. Vocationa Division Bulletin No. 207 (Trade and Industrial Series No. 58) : Th Fire Alarm System; an Analysis of the Work of the Fire Alarm Bureau, with a Discussion of the Problems of Training likely to be Encountered. By Frank Cushman and H. A. Friede. Pp. vii +78 15 cents. Vocational Division Leaflet No. 1: Teaching the Contro of Black Stem Rust of Small Grains in Vocational Agriculture Classes. Revised edition. Pp. iv +12. 5 cents. (Washington, D.C. : Govern-
ment Printing Office.) 